\title{
PELATIHAN PENINGKATAN KOMPETENSI PRA UJI KOMPETENSI KEJURUAN (UKK) JURUSAN TEKNIK OTOMOTIF KEPADA SISWA SMK RIGOMASI BONTANG
}

\author{
${ }^{1)}$ Ahmad Yani, ${ }^{2)}$ Yano Hurung Anoi, ${ }^{3)}$ Wildan Hamdani \\ ${ }^{122) 3)}$ Jurusan Teknik Mesin - Sekolah Tinggi Teknologi Industri Bontang \\ ${ }^{1)}$ Email: yanibima@gmail.com \\ ${ }^{2)}$ Email: yanodayak@yahoo.com \\ ${ }^{3)}$ Email: whandani@ pupukkaltim.com
}

\begin{abstract}
ABSTRAK
Pengabdian Masyarakat merupakan salah satu dari Tridharma Perguruan Tinggi yang wajib dilakukan oleh dosen. Uji Kompetensi Keahlian (UKK) adalah bagian dari intervensi Pemerintah dalam menjamin mutu pendidikan pada satuan pendidikan Sekolah Menengah Kejuruan. Pelaksanaan UKK bertujuan untuk mengukur pencapaian kompetensi siswa pada level tertentu sesuai kompetensi Keahlian yang ditempuh selama masa pembelajaran di SMK. Tujuan kegiatan pengabdian masyarakat ini adalah untuk mendukung persiapan siswa SMK Rigomasi pada Ujian Kompetensi Keahlian teknik otomotif yang setiap tahun diadakan dan meningkatkan pencapaian kompetensi siswa SMK Rigomasi. Berdasarkan hasil kegiatan dan pembahasan bahwa terdapat peningkatan pengetahuan dan keahlian tune up dan perbaikan engine management system yang cukup signifikan setelah melewati pelatihan yang ditandai dengan hasil perbandingan antara nilai pretest dengan post test. Dari hasil pengolahan data dapat disimpulkan bahwa nilai ujian post test maksimum sebesar 8,97.
\end{abstract}

Kata Kunci: Pelatihan, UKK, Teknik Otomotif, Siswa SMK. 


\section{PENDAHULUAN}

Sekolah Menengah Kejuruan (SMK) Rigomasi Bontang merupakan SMK pertama di Kota Bontang yang berdiri pada Tahun 1987, dengan seiringnya waktu hingga saat ini terdapat empat kompetensi keahlian yang menjadi produk unggulan sekolah, baik dari penyediaan tenaga kerja maupun pelayanan publik diantaranya Teknik Alat Berat, Teknik Kendaraan Ringan, Teknik Instalasi Tenaga Listrik, dan Teknik Komputer Jaringan.

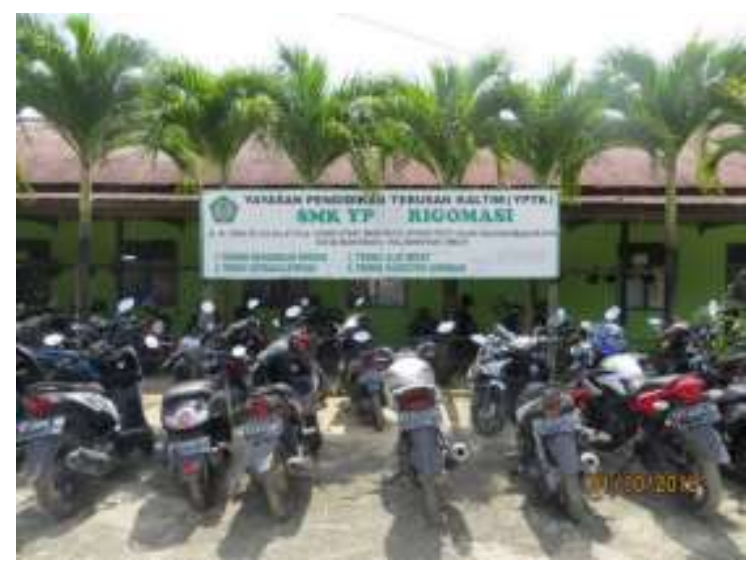

Gambar 1. SMK Rigomasi Bontang

Sumber: http://smkrigomasi.weebly.com

Tridharma Perguruan Tinggi adalah Pendidikan, Penelitian, dan Pengabdian Masyarakat. Salah satu kewajiban tersebut melaksanakan Pengabdian Masyarakat, hal ini dilaksanakan berkaitan dengan kepedulian setiap lembaga atau institusi yang bergerak dibidang Pendidikan (Qurohman, 2018). Berdasarkan kewajiban tersebut Dosen Teknik Mesin Sekolah Tinggi Teknologi Industri Bontang melakukan pengabdian masyarakat dengan melakukan pelatihan uji kompetensi kejuruan teknik otomotif. Dalam pendidikan kejuruan, SMK merupakan pendidikan pada jenjang menengah yang mempersiapkan dan mengembangkan kompetensi siswa untuk memasuki dunia kerja, sehingga kualifikasi lulusan SMK juga harus sesuai dengan kebutuhan dunia usaha dan insustri, (Irwanti, 2014).

Uji Kompetensi Keahlian (UKK) adalah bagian dari intervensi Pemerintah dalam menjamin mutu pendidikan pada satuan pendidikan Sekolah Menengah Kejuruan. Pelaksanaan UKK bertujuan untuk mengukur pencapaian kompetensi siswa pada level tertentu sesuai kompetensi Keahlian yang ditempuh selama masa pembelajaran di SMK. UKK dilaksanakan oleh satuan pendidikan dalam bentuk ujian praktik yang menguji aspek pengetahuan, keterampilan, dan 
sikap. Uji kompetensi keahlian sebagai bagian dari penilaian yang khas SMK adalah penilainan terhadap pencapaian siswa terkait kualifikasi jenjang dua atau tiga pada KKNI yang dilaksanakan di akhir masa studi oleh lembaga satuan pendidikan terakreditasi bersama mitra dunia usaha dunia industry (DUDI) dengan memperhatikan paspor keterampilan. Hasil uji kompetensi dari peserta didik akan menjadi indicator ketercapaian standar kompetensi lulusan, sedangkan bagi stakeholder akan dijadikan informasi atas kompetensi yang dimiliki oleh calon tenaga kerja. UKK adalah proses penilaian melalui pengumpulan bukti yang relevan untuk menentukan apakah seseorang kompeten atau belum kompeten pada suatu kualifikasi tertentu (BNSP. (2018).

Bertepatan dengan persiapan ujian kompeteni keahlian siswa SMK, maka diadakanlah kegiatan pelatihan peningkatan kompetensi untuk siswa - siswa SMK Rigomasi. Kegiatan pelatihan ini juga sekaligus sebagai kegaiatan pengabdian masyarakat yang dilaksanakan oleh dosen Teknik Mesin Sekolah Tinggi Teknologi Industri Bontang. Pengabdian Masyarakat merupakan salah satu dari Tridharma Perguruan Tinggi yang wajib dilakukan oleh dosen dan hal ini dilaksanakan berkaitan dengan kepedulian setiap lembaga atau institusi yang bergerak dibidang Pendidikan. Tujuan kegiatan pengabdian masyarakat ini adalah untuk mendukung persiapan siswa SMK Rigomasi pada Ujian Kompetensi Keahlian teknik otomotif yang setiap tahun diadakan dan merupakan bagian dari Ujian Nasional tingkat SMK dan Meningkatkan pencapaian kompetensi siswa SMK yang telah menyelesaikan proses pembelajaran sesuai kompetensi keahlian yang ditempuh.

\section{METODE}

\subsection{Lokasi Kegiatan}

Pengabdian masyarakat ini dilaksanakan di SMK Rigomasi Bontang Jalan A.Yani No. 1 Kelurahan Api-api - Kecamatan Bontang Utara - Kota Bontang - Kalimantan Timur.

\subsection{Materi Kegiatan}

Materi yang diberikan yaitu Tune-up dan Perbaikan Engine Management System antara lain:

1. Memeriksa engine oil

2. Memeriksa coolant

3. Memeriksa radiator cap

4. Memeriksa kebocoran cooling system

5. Memeriksa sirkulasi coolant

6. Mengukur tegangan battery

7. Memeriksa level dan berat jenis electrolyte 
8. Membersihkan tutup sel dan terminal battery

9. Memeriksa dan membersihkan drive belt

10. Menyetel ketegangan drive belt

11. Memeriksa dan membersihkan air filter

12. Memeriksa PCV Valve

13. Menyetel Valve clearence

14. Memeriksa kerja fuel pump

15. Memeriksa kerja injector

16. Mengukur resistansi injector

17. Memeriksa kerja spark plug (spark test)

18. Mengkondisikan mesin dan memeriksa elektroda spark plug

19. Menyetel celah elektroda dan membersihkan spark plug

20. Memeriksa kebocoran komponen fuel system/mengukur tekanan bahan bakar

21. Mengkondisikan mesin dan mengukur compression pressure

\subsection{Metode Pelaksanaan}

Pelaksanaan pengabdian masyarakat yang dilakukan menggunakan empat metode yaitu:

1. Presentasi materi dan pengarahan pelaksanaan

Metode ini digunakan untuk memberikan pengetahuan kepada peserta tentang tata cara dan materi yang akan diberikan pada pelatihan ini yaitu tune-up dan Perbaikan Engine Management System.

2. Pre test dan post test

Metode ini dilakukan untuk mengukur kemampuan siswa sebelum diberikan materi pelatihan dan setelah diberikan materi pelatihan dengan harapan untuk membandingkan peningkatan kompetensi peserta atau nilai sebelum dan sesudah pelatihan tersebut.

3. Demonstrasi dan tanya jawab

Setelah pelaksanaan metode pre test maka instruktur melakukan demonstrasi materi pelatihan pra UKK dengan cara langsung pada objek pelatihan yaitu pada engine stand gosaline dan diesel engine dengan harapan siswa langsung mengamati proses tune up mesin tersebut sehingga memudahkan siswa untuk memahami langkah kerjanya. Penggunaan metode tanya jawab dilakukan sebagai bentuk komunikasi yang dijalin antara instruktur dengan peserta. Metode tanya jawab dilakukan pada saat instruktur mendemostrasikan tune-up dan perbaikan Engine Management System dan dimaksudkan untuk merespon keingintahuan peserta mengenai teknik yang sedang diajarkan oleh instruktur.

\section{Praktek}

Metode praktek dilakukan supaya peserta pelatihan dapat langsung mengaplikasikan pengetahuan yang didapat dari penggunaan metode presentasi dan demonstrasi serta tanya jawab. 


\section{HASIL DAN PEMBAHASAN}

\subsection{Hasil Kegiatan Pelatihan}

Hasil pengabdian masyarakat ini merupakan uraian data dokumentasi kegiatan berupa gambar dan dokumentasi nilai kompetensi hasil yang diperoleh dari pelaksanaan pengabdian masyarakat di SMK Rigomasi Bontang.

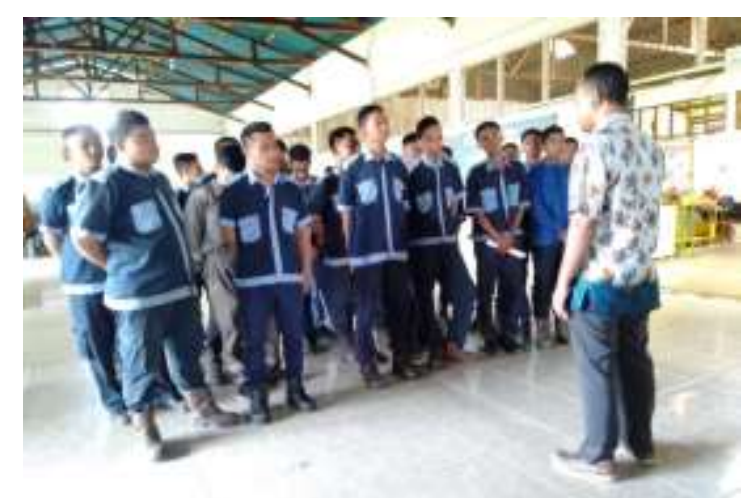

Gambar 2. Pengarahan kepada peserta Sumber. Dokumentasi tim lapangan

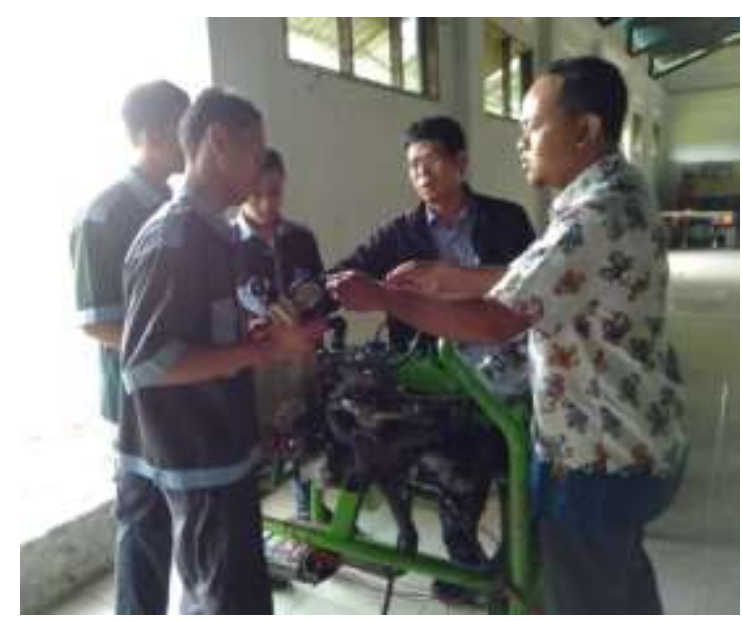

Gambar 3. Demonstrasi kepada peserta Sumber. Dokumentasi tim lapangan 


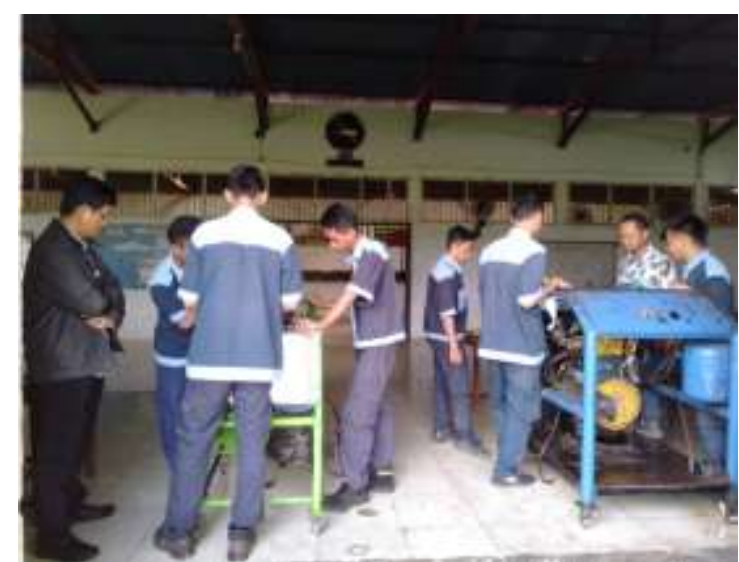

Gambar 4. Aktivitas Pelatihan oleh Tim PKM Sumber. Dokumentasi tim lapangan

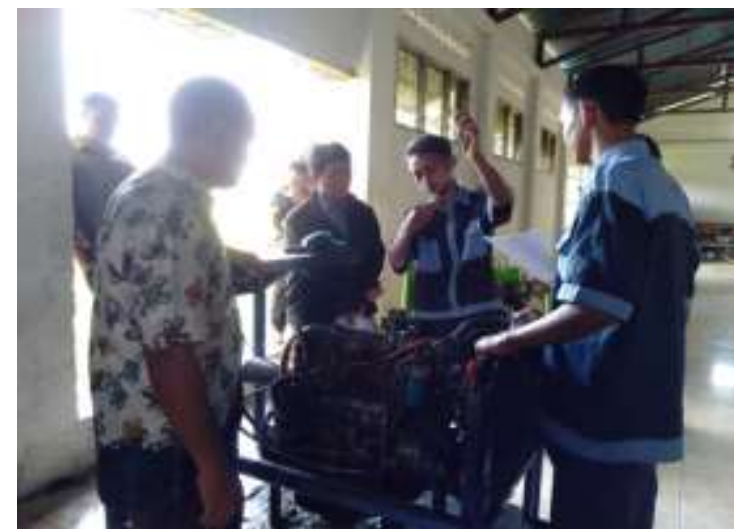

Gambar 5. Pengecekan volume oil engine Sumber. Dokumentasi tim lapangan

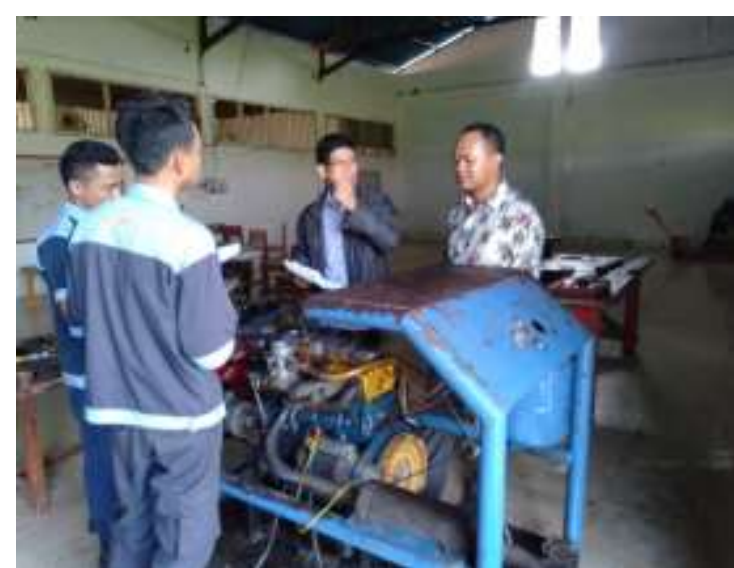

Gambar 6. Tanya jawab dengan instruktur Sumber. Dokumentasi tim lapangan 


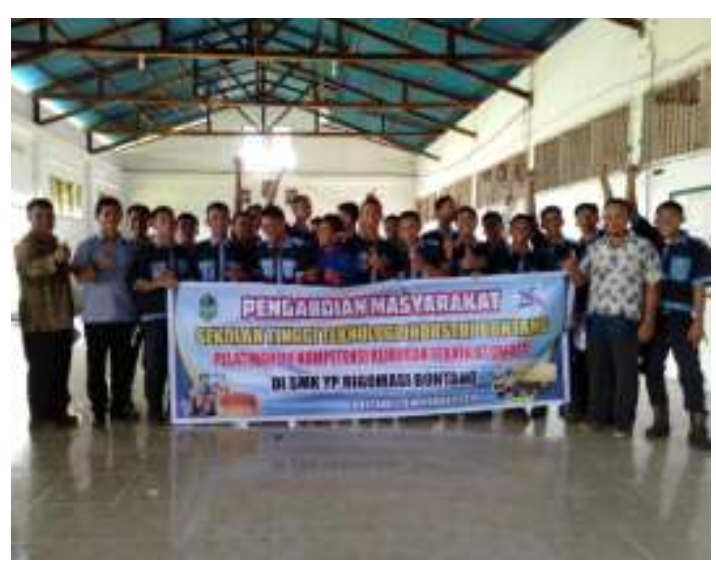

Gambar 7. Foto bersama dengan peserta Sumber. Dokumentasi tim lapangan

\subsection{Pembahasan Kegiatan Pelatihan}

Dalam pelaksanaan kegiatan ini terdapat tolak ukur dasar untuk mengetahui pencapaian kompetensi siswa sebelum pelatihan dan setelah pelatihan dengan cara melakukan pre test sebelum kegiatan dan melaksanakan post test setelah pelatihan. Hasil pre test dan post test peserta pelatihan dengan range mulai angka 0 sampai angka 10 dapat dilihat pada tabel 1.

Tabel 1. Hasil ujian pre test peserta sebelum kegiatan dan post test setelah pelatihan

\begin{tabular}{clccc} 
No & \multicolumn{1}{c}{ Nama Siswa } & NIS & Nilai Pre Test & Nilai Post Test \\
& & & & \\
\hline 1 & Ahmad Trismawardi & 5255 & 7.39 & 8.97 \\
2 & Andi Muhammad Fajjar & 5260 & 7.19 & 8.81 \\
3 & Andi Suyatno & 5262 & 7.37 & 8.88 \\
4 & Bagoes Septian & 5271 & 7.20 & 8.78 \\
5 & Denny Yusman & 5273 & 7.16 & 8.84 \\
6 & Enry Kusuma & 5071 & 7.12 & 8.80 \\
7 & Fitra Nur Yuda & 5287 & 7.37 & 8.75 \\
8 & Ilham & 5296 & 7.25 & 8.80 \\
9 & Indra Budiyono & 5297 & 7.40 & 8.85 \\
10 & Indra Setiyawan & 5298 & 7.30 & 8.88 \\
11 & Irfan & 5383 & 7.39 & 8.90 \\
12 & Irvan Susanto & 5091 & 7.26 & 8.86 \\
13 & Muhammad Arif Nur & 5318 & 7.27 & 8.87 \\
14 & Muhammad Fauzi & 5321 & 7.46 & 8.65 \\
15 & Nur Andi Alamsyah & 5330 & 7.14 & 8.86 \\
16 & Rachul Adha & 5408 & 7.17 & 8.74
\end{tabular}




\begin{tabular}{lllll}
17 & Riki Andi Shandika Pratama & 5342 & 7.30 & 8.80 \\
18 & Ronaldo Yakob & 5349 & 7.45 & 8.63 \\
19 & Syahriansyah Bumi Bahy & 5357 & 7.40 & 8.90 \\
20 & Tarsisus Wemfridts Mote & 5358 & 7.35 & 8.92 \\
21 & Yohanes & 5360 & 7.44 & 8.88 \\
\hline
\end{tabular}

Dari data tabel 1 tersebut kemudian dijadikan dalam bentuk grafik dan teknik analisa data menggunakan teknik deskriptif berdasarkan hasil ujian. Hubungan antara nilai pre test dan post test pada kegiatan pelatihan tune-up dan perbaikan engine management system seperti ditunjukkan gambar 8 .

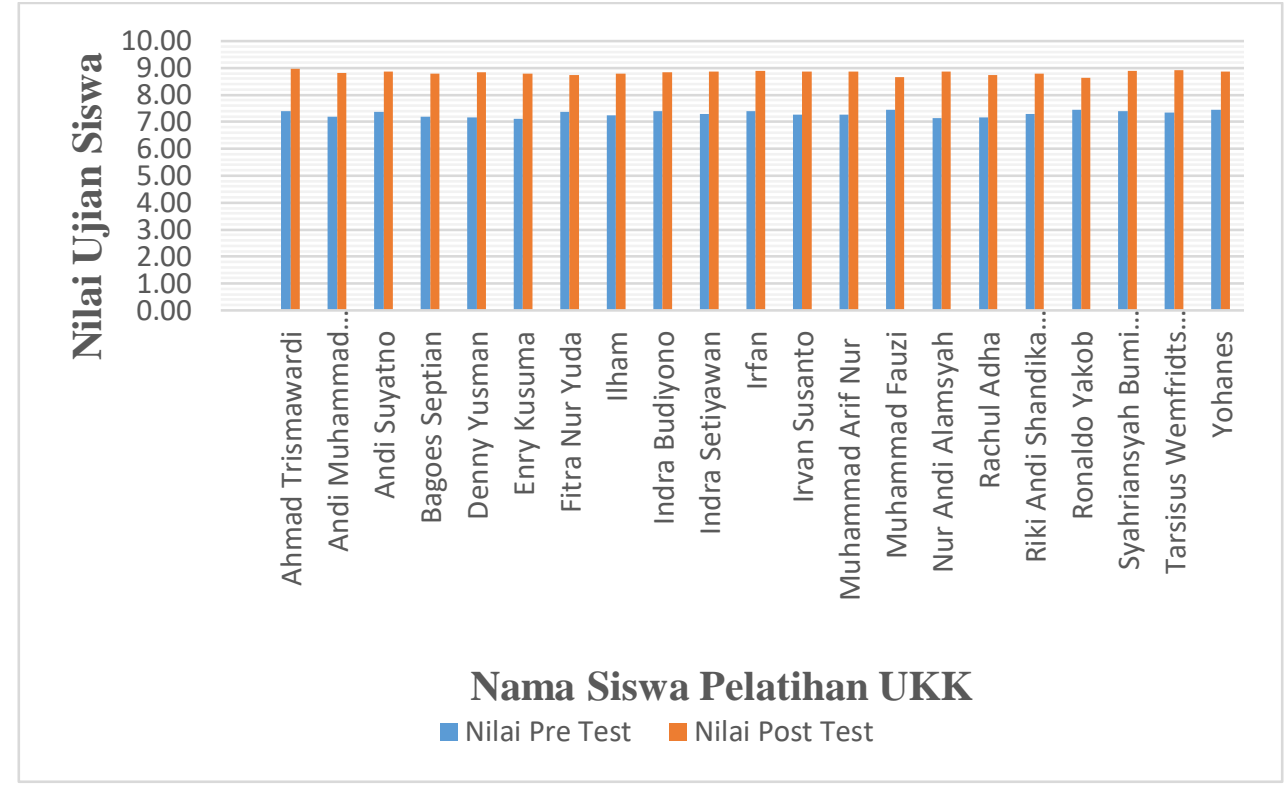

Gambar 8. Grafik nilai pre test dan post tes peserta pelatihan

Pelaksanaan pelatihan peningkatan kompetensi tune up dan perbaikan engine management system ini mendapat respon yang sangat positif dari peserta dengan indikasi antusian peserta dalam melakukan praktek dilapangan. Berdasarkan gambar 8 dapat dilihat bahwa dari 21 peserta pelatihan semua meningkat nilai kompetensi para peserta pelatihan dengan membandingkan grafik nilai pre test dengan post test. Berdasarkan pengamatan dan evaluasi yang dilakukan selama pelatihan, dapat dilaporkan bahwa kegiatan pengabdian masyarakat telah berhasil dilaksanakan dengan indikator keberhasilan yang telah dicapai dan dapat dilihat dari gambar 8 yaitu grafik nilai pre test dengan post test. Hasil yang didapatkan setelah melalui pelatihan ini adalah meningkatnya pengetahuan dan keterampilan siswa Jurusan Teknik Otomotif SMK 
Rigomasi Bontang tentang materi penguasaan Tune-up dan perbaikan engine management system. Berdasarkan hasil pengolahan data seperti ditunjukkan pada gambar 8 tersebut nilai ujian post test maksimum diperoleh Ahmad Trismawardi dengan nilai sebesar 8,97. Kemudian nilai ujian post test kedua diperoleh Tarsisus Wemfridts Mote dengan nilai sebesar 8,92. Kemudian nilai ujian post test ketiga diperoleh Irfan dan Syahriansyah Bumi Bahy dengan nilai sebesar 8,90. Dari hasil pengolahan data dapat disimpulkan bahwa nilai ujian post test maksimum sebesar 8,97.

\section{KESIMPULAN}

Terdapat peningkatan pengetahuan dan keahlian Tune-up dan perbaikan engine management system yang cukup signifikan setelah melewati pelatihan yang ditandai dengan hasil perbandingan antara nilai pretest dengan post test. Dari hasil pengolahan data dapat disimpulkan bahwa nilai ujian post test maksimum sebesar 8,97.

\section{DAFTAR PUSTAKA}

Qurohman, M. Taufik., Romadhon, S. Arif., \& Wulandari, R,. (2018). Peningkatan Kompetensi Siswa Dan Guru Smk Dinamika Kota Tegal tentang Pemanfaatan Program Komputasi Matematika Geogebra. Jurnal ABDIMAS Unmer Malang, Vol. 3, Edisi Khusus, Desember 2018, hal. 1-4.

BNSP. (2018) Pedoman penyelenggara uji kompetensi keahlian (ukk) SMK Tahun 2018/2019.

Jakarta: Direktorat Pembinaan Sekolah Menengah Kejuruan.

Irwanti, Y. Dwi (2014) Evaluasi uji kompetensi siswa keahlian multimedia di SMK se Kota Yogyakarta. Jurnal pendidikan Vokasi Vol. 4 No. 3 hal. 420-432

Depdiknas. (2003). Undang-Undang RI No. 20 Tahun 2003, tentang Sistem Pendidikan Nasional http://smkrigomasi.weebly.com 